\title{
Sağlık Turizminde Dijital İletişim Kanallarının Kullanımı*
}

\author{
The Use of Digital Communication Tools in Health Tourism
}

\author{
Doç. Dr. Burcu ÖKSÜZ \\ İzmir Katip Çelebi Üniversitesi \\ Sosyal ve Beşeri Bilimler Fakültesi \\ E-posta: oksuz.burcu@gmail.com
}

\author{
Doç. Dr. Volkan ALTINTAŞ \\ İzmir Katip Üniversitesi \\ Turizm Fakültesi \\ E-posta: volkan_altintas@hotmail.com
}

\section{Öz}

$\mathrm{Bu}$ çalışmanın amacı, İstanbul'da faaliyet gösteren ve $\mathrm{JCl}$ (Joint Commission International) akreditasyonu almış olan hastanelerin uluslararası kapsamda sağlık turistlerine ulaşmak amacıyla yürüttükleri dijital iletişim çalışmalarının ortaya konulmasıdır. Bu doğrultuda, hastanelerin İngilizce olarak hazırlanmış web sitelerine, İngilizce paylaşımlar yapılan Facebook ve Twitter hesaplarına yönelik içerik analizi yapılmış ve edinilen veriler değerlendirilmiştir. Araştırma bulgularına göre hastanelerin dijital iletişim kanallarında farklı dallarda verdikleri hizmetler, başarıları, hekimlerinin katıldıkları bilimsel toplantılar, ek hizmetler, sunulan ulaşım destekleri gibi konularda bilgi aktarımı yaptıkları, fotoğraf ve video paylaştıkları belirlenmiştir. Ancak hastanelerin dijital iletişimin etkileşim kurma olanağından yeterince faydalanamadığı saptanmıştır. Analiz sonuçlarına göre, dijital iletişim kanalları sağlık turizminde bir bilgi aktarım aracı olarak kullanılmaktadır.

Anahtar Kelimeler: Sağlık Turizmi, Dijital iletişim, Sağıı iletişimi, JCI.

\begin{abstract}
The purpose of this study is to reveal the digital communication work of hospitals which operates in Istanbul and are $\mathrm{JCl}$ (Joint Commission International) accredited, in order to reach health tourists within international scope. In this direction analysis were made for hospital's English web sites, Facebook and Twitter accounts which have English shares, and the obtained data is examined. It was determined that they transferred information, shared videos and photos in matters such as services in different branches given by the hospitals, the achievements, the scientific meetings attended by physicians, additional services and the offered transportation supports. However, it was determined that the hospitals have not been able to sufficiently benefit from the opportunity to interact in digital communications. According to results of the analysis, the hospitals use digital communications tools to share information in health tourism.
\end{abstract}

Keywords: Health Tourism, Digital communication, Health communication, JCI

*Bu çalışma "Sağlık İletişimi Sempozyumu, 5-6 Kasım 2015 Eskişehir" adlı sempozyumda sözlü olarak sunulmuş bildirinin geliştirilmiş halidir. 


\section{Giriş}

İletişim, turizm sektörü açısından büyük önem taşımaktadır. Belirli stratejiler doğrultusunda yürütülen iletişim çalışmaları, ülkelerin kendilerini en doğru ve açık şekilde anlatmasını sağlayarak turistler tarafından tercih edilirliğe katkı sunar. Birçok destinasyona ve çok çeşitli turizm olanaklarına sahip olan Türkiye'nin destinasyonlarının sahip oldukları zenginliklere ve özelliklere dayanarak iletişim stratejileri oluşturması ve entegre mesajlar kullanması, bilinirliği ve tercih edilirliği arttıracak olan önemli bir faktördür. İletişim teknolojilerinin gelişimi ve bu doğrultuda web siteleri, sosyal medya gibi araçların kullanımının artması destinasyonların tanıtımında yeni fırsatlar sunmuştur. Destinasyonlar, dünyanın farklı bölgelerinde yaşayan insanlara kendilerini daha hızlı ve maliyetsiz şekilde tanıtabilme olanağı elde etmiştir. Dijital iletişimin etkili şekilde kullanılabildiği alanlardan biri de sağlık turizmidir.

Sağlık turizmi Türkiye'de önemi gün geçtikçe artan bir turizm türüdür. Sağlık Bakanlığı'nın Türkiye'de sağlık turizminin geliştirilmesine ve sağlık turistlerinin sayısının arttırılmasına yönelik çalışmaları bulunmaktadır. Sağlık turizminde ülkelerin genel stratejileri ve uygulamaları oldukça önemlidir. Ancak bunların yanı sıra sağlık hizmeti veren hastanelerin yürüttükleri çalışmalar da sağlık turizminin başarısının temel belirleyicilerinden olmaktadır. İletişim faaliyetleri ise sağlık hizmetlerinin anlatılması, intiyaçların ve beklentilerin öğrenilmesi, sağlık turistlerine ulaşılması ve memnuniyetlerinin ölçülmesi gibi pek çok konuda önemli roller üstlenmektedir. Dolayısıyla gerek ülkelerin, gerekse o ülkede faaliyet gösteren hastanelerin sağlık turizmi çabalarında iletişim, isteğe bağlı olmanın ötesinde bir zorunluluk olarak görülmelidir. Belirli stratejiler dâhilinde ve geniş bir yelpazede iletişim kanalları kullanılarak, farklı ülkelerde yaşayan turistlere ulaşılabilmeli ve verilen hizmetlerin kalitesi aktarılabilmelidir. Şöyle ki sağlık amacıyla bir ülkeye seyahat etmek, her şeyden önce ülkeye, hastaneye ve sağlık hizmeti veren görevlilere güven duyabilmeyi gerektirir. Bu güvenin oluşturulmasının temelinde ise sürekli, tutarlı ve açık iletişim yatar. Sağlık turistleri, gidecekleri ülkeye ve hastaneye karar vermeden önce detaylı bilgi arayışı içerisine girer. Bu bağlamda iletişim teknolojilerinde yaşanan gelişmeler, hastanelere sağlık turistlerine ulaşmak ve onları bilgilendirmek açısından fırsatlar yaratmıştır.

Deloitte (2008) şirketinin yaptığı araştırmanın bulgularına göre sağlık turizminde en çok ziyaret edilen ülkeler arasında Hindistan, Tayland, Meksika, Filipinler, Kore, Tayvan, Malezya ve Singapur öne çıkmaktadır (Aydın ve Aydın, 2015: 4). Türkiye Medikal Turizm Değerlendirme Raporu'nda (2013) belirtildiği şekilde ise 2011 yılında Türkiye'de sağlık hizmeti alan uluslararası hasta sayısı 156.176 olurken, 2012 yılı için bu sayı yaklaşık 262.000'e ulaşmıştır. Dolayısıyla yaklaşık \% 68 oranında bir artış olmuştur. Sağlık Bakanlığı'nın 2013-2017 Stratejik Eylem Planı'nda yer alan Türkiye'de sağlık turizmini güçlendirmeye yönelik hedefin gerçekleştirilmesine ilişkin stratejilerden biri 'Sağlık turizmi kapsamında tanıtım yapmak ve cazibe oluşturmak' olarak belirtilmiştir. Bu anlamda Türkiye'nin sahip olduğu sağlık turizmi potansiyelinden yararlanabilmesi, iletişim ve tanıtım çalışmalarının etkili şekilde yürütülmesini zorunlu kılmaktadır.

$\mathrm{Bu}$ çalışmanın amacı, İstanbul'da faaliyet gösteren $\mathrm{JCl}$ akreditasyonuna sahip olan hastanelerin sağlık turizmi kapsamında dijital iletişimi nasıl kullandıklarını ortaya koymaktır. Çalışma kapsamında öncelikle sağlık turizmi ve sağlık turizminde dijital iletişim araçlarının kullanımı açıklanmış, daha sonra hastanelerin İngilizce web sitelerine ve sosyal medya hesaplarına yönelik bir araştırma gerçekleştirilmiştir. 


\section{Sağlık Turizmi}

Dünya Sağlık Örgütü (World Health Organization-WHO) sağığı "yalnızca hastalık veya sakatlık durumunun olmaması değil; fiziksel, zihinsel ve sosyal olarak tam bir iyilik hali" olarak tanımlamaktadır (2006). Sağlık turizmi ise kişilerin ruhsal ve bedensel iyilik durumlarının korunması, geliştirilmesi ve iyileştirilmesi için bulunduğu çevrenin dışına yönelik organize seyahatleridir (Carrera ve Bridges, 2006: 447). Başka bir tanımla sağlık turizmi, "sağlık bakım hizmeti almak için başka bir ülkeye seyahat etmek" (Gülen ve Demirci, 2012: 14) olarak açıklanmaktadır. Muğla Valiliği'nin 'Muğla İli Turizm Sektörünün Uluslararası Rekabetçilik Analizi' raporunda (2010: 104) sağlık turizmi "Tedavi amacından hareketle başlayan ve tedavi unsurlarının beraberinde tatil unsurlarını da kapsayan seyahatler konaklamalar ve organizasyonlardan doğan olay ve ilişkilerin bütünü" olarak tanımlanmaktadır. Sağlık Bakanlığı ise "İkamet edilen yerden başka bir yere (yurtiçi veya yurtdışı) her hangi bir sağlık sebebiyle hizmet almak için yapılan seyahatler" (http://saglikturizmi.gov.tr) olarak açıklar.

Yukarıda yer verilen tanımlarda belirtildiği şekilde sağlık turizmi en temel şekliyle, kişilerin ikamet ettikleri yerlerin dışına sağlık hizmeti almak amacıyla seyahat etmesidir. Bu çalışma kapsamında sağlık turizminin yurt dışına yönelik seyahatleri kapsadığı kabul edilse de, seyahatlerin yurt içine veya yurt dışına olması konusunda farklı görüşler bulunmaktadır. İlgili literatürde yer alan bazı çalışmalarda sağlık turizmi kapsamında değerlendirilebilmesi için seyahat edilen yerin yurt dışında olması gerektiği dile getirilirken, Sağıık Bakanlığı sağlık turizmi kapsamındaki seyahatleri hem yurt içi hem de yurt dışı olarak görmektedir.

Sağlık turizminden söz ederken sağlık turistinin de kim olduğunun açıklanması gereği bulunmaktadır. "Sağlık turisti, öncelikle tedavi amacından hareketle seyahat eden ve tatil unsurlarını içeren ürün ve hizmetleri de talep ederek sağlık turizmi kapsamında sunulan çeşitli mal ve hizmetleri satın alan kişidir." (Muğla Valiliği Rekabetçilik Analizi Raporu, 2010: 104). Dolayısıyla sağlık turisti, yalnızca sağlık hizmeti satın almamakta, bunun yanı sıra gittiği yerde tatil yapmakta ve sunulan diğer olanaklardan faydalanmaktadır. Bu noktada sağlık turizmini sağlık hizmetini ve tatili içine alan bütünsel bir hizmet olarak görmek yerinde olacaktır. .

Turistleri, sağlık turizmine yönelten pek çok faktör bulunmaktadır. Neredeyse hiç bekleme sürelerinin olmaması, yüksek kaliteye anında ulaşım, düşük maliyetli tıbbi ilgi, ihtiyaç olan zamanda mükemmel tıbbi ve cerrahi tedavi, gelişmiş ülkelerde sağlık bakımı maliyetlerinin hızla yükselmesi, sağlık sigortası dışında tutulan tedaviler, kolay ve ucuz uluslararası seyahat, küresel ekonomide döviz kurlarında problem olmaması, dünyadaki birçok ülkede tıbbi bakım standartlarında son teknoloji ve yüksek kalite olması, bazı gelişmekte olan ülkelerde sağlık bakımında güvenin kanıtlanmış olması, yeninin ve farklılıkların çekiciliği (Woodman, 2009; MacReady, 2007; Srivastava, 2006) gibi birçok neden kişileri bulundukları yerin dışında sağlık hizmeti almak amacıyla seyahate yönlendirmektedir.

Sağlık turizmi yalnızca tıbbi tedavileri içermez. Sağlık Bakanlığı sağlık turizmini medikal turizm, geriatri ve engelli turizmi ve termal turizm olmak üzere 3 boyutta incelemektedir (www.saglikturizmi.gov.tr).

Medikal Turizm: Tıbbi, dental ve cerrahi tedavi almak amacıyla diğer ülkelere seyahat edilmesi olarak tanımlanmaktadır (Srivastava, 2006, s. 140). Diğer bir tanımla medikal turizm "genel olarak cerrahi veya özel uzmanlık gerektiren diğer tıbbi müdahaleleri içeren uygulamalara intiyaç gösteren hastalara "maliyet etkili" özel tıbbi 
bakım verilmesi maksadıyla turizm endüstrisi ile işbirliği yapılmasıdır." (Özsarı ve Karatana, 2013: 140). Medikal turistler genellikle gelişmiş ülkelerden ağırlıklı olarak ABD, Kanada, Birleşik Krallık, Batı Avrupa ve Orta Doğu'dan gelmektedirler (Srivastava, 2006, s. 140).

Geriatri ve Engelli Turizmi: Geriatri turizmi "yaşı bireylerin sağlığının korunması, gelişebilecek hastalıkların önlenmesi, tanı ve tedavilerine yönelik yapılan seyahatlerdir" (Muğla Valiliği Rekabetçilik Analizi Raporu, 2010: 107). 65 yaş ve üzeri insanların özellikle son 20-30 yılda artan yaş ortalamalarına paralel olarak bakım gerektiren tedavileri kapsayan bir sağlık turizmi çeşididir (http://www.turkey-healthtourism.com).

Termal Turizm: "Mineralize termal su banyosu, içme, inhalasyon, çamur banyosu gibi çeşitli türdeki yöntemlerin yanında, iklim kürü, fizik tedavi, rehabilitasyon, egzersiz, psikoterapi, diyet gibi destek tedavilerin birleştirilmesi ile yapılan kür (tedavi) uygulamaları için meydana gelen turizm hareketi” (Özsarı ve Karatana, 2013: 138-139) şeklinde tanımlanmaktadır."Termo-mineral su banyosu, içme, inhalasyon, çamur banyosu gibi çeşitli türdeki yöntemlerin yanında iklim kürü, fizik tedavi, rehabilitasyon, egzersiz, psikoterapi, diyet gibi destek tedavilerinin birleştirilmesi ile yapılan kür uygulamalarının yanı sıra termal suların eğlence ve rekreasyon amaçlı kullanımı ile meydana gelen turizm türüdür" (Muğla Valiliği Rekabetçilik Analizi Raporu, 2010: 106).

Türkiye sahip olduğu zengin olanaklar nedeniyle sağlık turizminin farklı alanları açısından büyük potansiyele sahip bir ülkedir (Aydın ve Aydın, 2015; Edinsel ve Adıgüzel, 2014). Sağlık turizminin gelişimi kurumların işbirliği, uygulamaların entegrasyonu, sürekli değerlendirme gibi faktörlerin yanında stratejilerle uyumlu iletişim çalışmalarını gerekli kılmaktadır.

\section{Sağlık Turizmi ve Dijital İletişim}

Bilgi iletişim teknolojileri, iletişimi kolaylaştırmış ve mahiyetini değiştirmiştir (Hvass ve Munar, 2012: 93). "Yeni iletişim teknolojilerinin gelişmesi ve yaygınlaşması başta sosyal, siyasal, kültürel ve ekonomik alanlar olmak üzere hemen her alanın da kendi içerisinde yenilenmesini, yeni iletişim teknolojileri ile birlikte gelen değişim ve gelişimden etkilenmesi sonucunu doğurmuştur." (Yurdakul ve Coşkun 2008: 142). İletişimin yeni yapısı, sektörlerin ve işletmelerin uygulamalarında da büyük değişiklikler yaratmıştır. Turizm, yeni bilgi ve iletişim teknolojileriyle yakından ilişkili sektörlerden biridir (Miguéns ve diğ., 2008: 2). Sağlık turizminde gerek dünyanın farklı yerlerinde ikamet eden turistlere ulaşmak, gerekse onların değerlendirmelerini almak ve güven oluşturmak açısından iletişim teknolojileri büyük fırsatlar yaratmıştır.

Tüketicilerin sahip oldukları bilgi, uyumlu bilgi arayışları, satın alma niyetleri ve karar verme süreçlerinde etkili olmaktadır (Sharifpour vd., 2013; Dodd vd., 2005; Rao ve Monroe, 1988; Brucks, 1985). Bundan dolayı destinasyonlar ve faaliyet gösteren işletmeler turistlerin kararlarında etkili olacak bilgileri detaylı şekilde sunabilmelidir. İstenilen bilgilere ulaşamayan turistler, bilgi boşluklarını farklı kaynaklardan elde edecekleri bilgilerle dolduracak ve bu bilgilere dayanarak kararlarını verecektir. Farklı kaynaklardan yayılan bilgileri denetlemek, destinasyonların kontrolü altında değildir. Bu nedenle mümkün olduğunca doğru bilgileri sürekli olarak yaymak, turistlerin aradıkları bilgileri sunabilmek açısından oldukça önemlidir. Turistlerin bilgi aramakta kullandıkları iletişim kanallarının daha çok dijital hale gelmesi, destinasyonları dijital kanalları etkili şekilde yönetebilme zorunluluğu ile baş başa bırakmıştır. Dolayısıyla kendini anlatmak ve daha fazla turist çekmek isteyen destinasyonların geleneksel ve dijital iletişim ortamlarında entegre ve sürekliliği olan mesajlar vermesi gerekmektedir. 
Destinasyonlar sosyal medyaya odaklanan iyi şekilde geliştirilmiş iletişim stratejileri ile farklıılk yaratabilir ve diğer destinasyonlardan ayırt edilebilirler (Királ'ová ve Pavlíčeka, 2015; Pabel ve Prideaux, 2015; Xiang ve Gretzel, 2010; Schmallegger ve Carson, 2008).

Destinasyonların farklılaşmasının anahtarı, temel satış vaadinin keşfedilmesinden ve destinasyonun 'eşsiz ve değerli' turizm özelliklerinin mevcut ve potansiyel müşterilere tanıtılmasından geçmektedir (Mulec, 2000: 14). Bir destinasyona ilişkin farkındalıkta iki bilgi aracısı görülmektedir: Bunlar aracının bir destinasyon hakkında bilgiye maruz bırakma düzeyi ve doğrudan turizm deneyimi olarak gösterilmektedir. Bilgiye maruz kalma, resmi kontrol edilen kaynaklardan (yazılı ve radyo/TV reklamları, ücretli programlar ve teşvik programları gibi), genel medya kaynakları (gazete ve dergi yazıları) ve resmi olmayan kaynaklar (arkadaşlar, akrabalar, müşteriler ve diğer aracılar) olmak üzere çok çeşitli kaynaklardan gelebilmektedir (Klenosky ve Gitelson, 1998: 664).

Müşteri kararları giderek artan derecede duygusal tepkilerden ve tetikleyicilerden etkilenmektedir (Mulec 2000: 14). Potansiyel turistler, önemli destinasyon özellikleri konusunda nesnel ölçümlere ulaşmakta zorluk yaşamaktadır (Tapachai ve Waryszak 2000: 37). Dolayısıyla destinasyon kararları gerçek özelliklerden ziyade destinasyonun sembolik öğelerine dayanabilmektedir (Mackay ve Fesenmaier 2000: 417). Bir turizm ürünü, ziyaret edilmeden denenmediği için nesnel ölçümlerden ziyade öznel yargıları gerektirir (Tapachai ve Waryszak 2000: 37) ve turistlerin destinasyonlara ilişkin öznel algıları, destinasyon seçimlerini etkilemektedir (Chon 1990). Diğer bir deyişle, seyahat kararı verilmesinde destinasyonun imajı önemli bir rol oynamaktadır (Tapachai ve Waryszak 2000: 37). Başka bir görüşle turistlerin gerçek bir deneyim yaşamadan bir destinasyona ilişkin açık bir imaj oluşturmaları zordur (Govers ve Go, 2003). Destinasyonlar yürüttükleri iletişim çalışmaları ile yalnızca bilgi sunmazlar, aynı zamanda turistlere yaşayacakları güzel bir tatil konusunda vaatlerde bulunurlar. Görsel ve işitsel malzemelerle desteklenen bilgiler, turistlerin neden kendilerini seçmeleri konusunda sorulara cevap verirler. Ağızdan ağıza iletişimin özellikle turizm gibi önceden denenmeyen hizmetlerde ne kadar belirleyici olduğu açıktır. Destinasyonların ağızdan ağıza yayılan bilgilerinde farkında olması, yürüteceği iletişim çalışmalarının içeriğini oluşturmaları açısından kritik önem taşır. Şöyle ki Morgan ve diğerlerinin (2011) belirttiği gibi bir 'yer' ancak turizm tanıtımı ile anlatılar ve hikâyeler iletildiğinde 'destinasyon' haline gelmektedir. Sağıı turizmi açısından bakıldığında, destinasyonun kaliteli sağlık hizmeti sunan, sağlık turistlerinin beklentilerini karşılayan, turistlere iyi davranılan, verilen paranın karşılığının alındığı bir yer olarak algılanması sağlanmalıdır. Geleneksel ve dijital iletişim mesajlarının tutarlıı̆ı ve entegrasyonu ile sağlık turistlerinin nesnel ve öznel beklentilerinin karşılandığı bir destinasyon imajı yaratılabilmelidir.

Sağlık turizmi, dijital iletişimin etkili şekilde kullanılmasını gerektiren en önemli alanlardan birisidir. Bulundukları yer dışında sağlık hizmeti alacak kişilerin her şeyden önce gidecekleri yer hakkında detaylı bilgiye sahip olmak isteyeceği açıktır. Geleneksel iletişimin gerek hız gerekse maliyet açısından ulaşamayacağı yerlere ve kişilere dijital iletişim kanalları ile rahatlıkla ulaşılabilmekte ve sağlık turistlerinin ihtiyacı olan bilgiler detaylı şekilde sunulabilmektedir. Bunun yanı sıra özellikle sosyal medya kanallarının etkileşime olanak veren yapısı soruların cevaplanması ve sağlık turistlerinin iletişim sürecinin bir parçası olmaları açısından kritik bir önem taşır (Királová ve Pavlíčeka; Leung vd., 2013; Kietzmann vd., 2011; Xiang ve Gretzel, 2010). 
Sosyal medya, sağlık turizminde elektronik ağızdan ağıza iletişim (e-WOM) açısından da olanaklar sunmaktadır. Ağızdan ağıza iletişim, "belirli ürün ya da hizmetlerin sahipliği, kullanımı, özellikleri veya satıcıları hakkında diğer tüketicilere yönelik resmi olmayan iletişim" olarak tanımlanmaktadır (Westbrook, 1987: 261). Litvin ve diğerleri (2008) ağızdan ağıza iletişimde ticari kaygılar olmadığı için turistlerin bu mesajları daha güvenilir bulduğunu ve ticari kaynaklardan gelen bilgilere göre ağızdan ağıza iletişimden daha fazla etkilendiklerini ileri sürerler. İletişim teknolojilerinde yaşanan gelişmeler, ağızdan ağıza iletişimin dijital ortamlarda da gerçekleşmesine zemin hazırlamıştır. İnternet, tüketicilerden ürünle ilgili bilgi edinebilmek için boykot siteleri, ziyaretçi defterleri, müşteri sohbetleri, tartışma forumları gibi pek çok yol sunmaktadır (Hennig-Thurau ve Walsh, 2003: 52). Elektronik ağızdan ağıza iletişim, insanların birbiriyle doğrudan iletişim kurduğu ve satın alma tercihleri, duyguları ve rahatsız edici deneyimleri hakkında konuştuğu sosyal medyanın doğuşu ile ivme kazanmıştır (Eikelmann vd., 2008). Sosyal medyada bilgi arayan tüketiciler, yalnızca sosyal ağlarında bulunan arkadaşlarından veya tanıdıklarından değil aynı zamanda tüm dünyada internet kullanıcısı olan kişilerden bilgi edinmektedir (Leung vd., 2013: 8). Sağlık turizmi kapsamında değerlendirildiğinde sosyal medya, sağlık hizmeti alan veya almayı düşünen kişilerin deneyimlerini, kaygılarını ve önerilerini birbirleriyle paylaştıkları bir mecra olarak fırsatlar sunar.

Woodman (2009) kilit kişilerle olan temaslarda rahat ve güvenilir iletişim kurmanın bir sağlık turisti olarak başarıdaki büyük önemine dikkat çeker. "Sağlık turizminin önündeki en büyük engel duygusal güvenlik intiyacıdır. Hastalar bilmedikleri bir çevreden sağlık hizmeti almak istememekte, arkadaşlarının ve ailesinin yanında tedavi olmak istemektedir." (Özsarı ve Karatana, 2013: 138). Bu noktada sağlık turistlerinin gittikleri yerlerin ve sağlık hizmeti aldıkları hastanelerin/sağlık çalışanlarının güvenilir olduklarına dair algılar ancak iletişim çalışmalarının etkili şekilde yürütülmesi ile gerçekleşebilir. Gidecekleri yerin nasıl bir yer olduğu, daha önce hizmet alanların memnun kalıp kalmadıkları, tıbbi teknolojinin durumu, kalacakları odanın dizaynı vs. gibi pek çok soru, web siteleri ve sosyal medya kanallarında verilen bilgilerle açıklığa kavuşturulmaktadır. Destinasyonların ve sağlık turizmi alanında hizmet veren kurumların dijital iletişimle sınırları aşarak turistlere ulaşabilmeleri ve hizmetlerini aktararak seyahat kararlarını etkilemeleri dijital iletişimle çok daha kolay ve maliyetsizdir. Günümüzde diğer turistlere benzer şekilde sağlık turistlerinin de ilk bilgi arayacakları yerlerin dijital kanallar olduğu düşünüldüğünde, dijital iletişimin sağlık turizminde ne kadar önemli olduğu açığa çıkmaktadır.

\section{Araştırmanın Yöntemi}

Bu çalışmada, İstanbul'da faaliyet gösteren ve $\mathrm{JCl}$ (Joint Commission International) akreditasyonu almış olan hastanelerin uluslararası kapsamda sağlık turistlerine ulaşmak amacıyla yürüttükleri dijital iletişim çalışmalarının ortaya konulması amaçlanmıştır. Bu doğrultuda İngilizce kurumsal web sitelerine, Facebook ve Twitter hesaplarına yönelik içerik analizi yapılmıştır.

"JCl, kalite ve hasta güvenliği alanındaki en iyi uygulamaları belirleyen, ölçümleyen ve dünyayla paylaşan; akreditasyon, kaliteli bakım ve hasta güvenliğinin bütün boyutlarını ele alan dünya çapında bir kuruluştur (http://tr.jointcommissioninternational.org). Çalışma kapsamında araştırmaya konu olan İstanbul'da faaliyet gösteren ve $\mathrm{JCl}$ akreditasyonuna sahip olan hastaneler aşağıdaki tabloda yer almaktadır. 
Tablo 1: Çalışma Kapsamında Yer Alan Hastaneler ve Akredite Tarihleri

\begin{tabular}{|l|l|}
\hline Hastane Adı & JCI Akredite Tarihi \\
\hline Acıbadem Hastanesi (Maslak) & 2 Ekim 2010 \\
\hline Amerikan Hastanesi & 15 Aralık 2002 \\
\hline Dünya Göz Hastanesi & 19 Temmuz 2006 \\
\hline Emsey Hastanesi & 30 Ağustos 2014 \\
\hline Fatih Üniversitesi -Sema Hastanesi & 19 Aralık 2008 \\
\hline Florence Nightingale (Gayrettepe) & 26 Haziran 2003 \\
\hline Florence Nightingale (İstanbul) & 23 Ağustos 2013 \\
\hline Florence Nightingale (Kadıköy) & 12 Haziran 2009 \\
\hline Florence Nightingale Hastanesi (Şişli) & 17 Nisan 2004 \\
\hline Hisar Intercontinental Hastanesi & 20 Ocak 2007 \\
\hline Liv Hastanesi & 3 Ağustos 2013 \\
\hline Medical Park Hastanesi (Bahçelievler) & 14 Kasım 2008 \\
\hline Medical Park Hastanesi (Göztepe) & 22 Kasım 2008 \\
\hline Medipol Hastanesi & 1 Mart 2014 \\
\hline Medicana Hastanesi & 20 Şubat 2010 \\
\hline Medistate Kavacık Hastanesi & 11 Nisan 2014 \\
\hline Memorial Ataşehir Hastanesi & 22 Eylül 2012 \\
\hline Memorial Şişli Hastanesi & 29 Mart 2002 \\
\hline NP İstanbul Neuropsychiatry Hastanesi & 20 Ocak 2012 \\
\hline Özel Pendik Bölge Hastanesi & 10 Haziran 2011 \\
\hline Yeditepe Üniversitesi Hastanesi & 2 Kasım 2007 \\
\hline
\end{tabular}

Yukarıdaki tabloda yer alan grup hastanelerinin genel olarak oluşturulmuş tek web siteleri ve sosyal medya hesapları çalışmaya dâhil edilmiştir. Hastanelerin kurumsal web sitelerinin İngilizce versiyonlarında verilen Facebook ve Twitter linklerinden sosyal medya hesaplarına ulaşılmıştır. Diğer bir deyişle, araştırmacılar sosyal ağlarda hastanenin ismi ile arama yapmamış, bunun yerine hastanenin uluslararası hastalara verdiği linkleri temel almıştır. Böylece yanlış sosyal medya hesaplarının incelenmesinin önüne geçilmeye çalışılmıştır. Analiz, hastanelerin paylaştıkları tüm içeriklere yönelik olarak 2015 yılının Ağustos ve Eylül aylarında yapılmıştır. Hataların önüne geçilmesi amacıyla, aynı sayfalar iki araştırmacı tarafından da ayrı olarak incelenmiştir.

Kurumsal web sitelerinin analizinde Mason ve Wright'ın (2011) çalışmalarında kullandıkları yöntem esas alınmıştır. Bu yöntemde web siteleri başvuru, güven, risk, ödeme ve maddi bilgiler ile genel bilgi açısından analiz edilmiştir.

Kurumsal web sitelerinin görsellerinin analizinde ise Crooks ve diğerlerinin (2011) çalışmasında kullandıkları yöntem esas alınmıştır. Görseller hastanenin dış görünüşü, teşhis veya görüntüleme cihazları, hastane/tesis logosu turist/seyahat görüntüleri, prosedürlerin seyri, hekimlerle ziyaret, iyileşme sonrası hemşirelik bakımı, personel fotoğrafları, hastanenin içindekiler ve haritalar başlıkları altında değerlendirilmiştir.

Sosyal medya hesaplarının incelenmesinde ise Neiger ve diğerlerinin (2012) çalışmalarında kullandıkları sınıflamadan yola çıkılmıştır. Bu çalışmada sağlıkta sosyal medya kullanımının temel performans göstergeleri öngörüler, maruz kalma, erişim ve etkileşim (alt düzey-orta düzey-üst düzey) olarak sıralanmaktadır.

\section{Bulgular}

Araştırma sonucunda hastanelerin sağlık turizmi kapsamında dijital iletişim kanallarını nasıl kullandıkları yönünde bulgular elde edilmiştir. Bulgular kurumsal web sitelerine, 
Facebook hesaplarına ve Twitter hesaplarına ilişkin olmak üzere üç başlık altında sınıflandırılmıştır.

\subsection{Kurumsal Web Sitelerine İlişkin Bulgular}

Yapılan incelemelerde araştırma kapsamındaki hastanelerden biri dışında tümünün uluslararası sağlık turistlerine/hastalara yönelik hazırlanmış İngilizce web sitelerine/sayfalarına sahip oldukları saptanmıştır. Araştırma bulguları aşağıda yer alan tabloda gösterilmiştir.

Tablo 2: Başvurularla İlgili Bilgiler

\begin{tabular}{|l|c|}
\hline Öğeler & - \\
\hline Düşük maliyet & 1 \\
\hline Beklemenin olmaması & 15 \\
\hline Yüksek kalitede hizmetler & 13 \\
\hline Son teknolojik hizmetler & 11 \\
\hline Son teknolojiye erişim & 14 \\
\hline Hekim ve cerrah uzmanlığı & 5 \\
\hline Kişiselleştirilmiş hizmetler & - \\
\hline Hastane kalış sürelerinin uzunluğu & 8 \\
\hline Büyük kolaylıklar sunulması & 11 \\
\hline Seyahat olanağı & \\
\hline
\end{tabular}

Hastanelerin İngilizce web siteleri incelendiğinde 15 web sitesinde ilk başvuru ile ilgili olarak yüksek kalitede hizmetler, hekim ve cerrah uzmanlığı, son teknolojik hizmetler ve son teknolojiye erişim ile bölgeye seyahat olanaklarına ait bilgilerin ağırıklı olduğu görülmektedir. Düşük maliyet ve hastanede kalış süresine ilişkin hiçbir net bilgiye ulaşılamamış olması, ilk bakışta hastaneye ulaşacak turistler açısından eksik görülen bir noktadır.

Tablo 3: Güvenle İlgili Bilgiler

\begin{tabular}{|l|c|}
\hline Öğeler & 14 \\
\hline Akreditasyon & 1 \\
\hline Akredite örgütlerine linkler bulunması & 12 \\
\hline Hekim veya personel biyografisi ve eğitimi & 15 \\
\hline Logo-markalama sembolü & 10 \\
\hline Tanıkların kullanımı & \\
\hline
\end{tabular}

Hastaneye olan güven konusunda 15 hastanenin web sitesi incelendiğinde sırasıyla akreditasyon, logo-markalamaya ilişkin sembol, hekim ve personel biyografisi ve eğitimi ile tanıkların kullanımı ön plana çıkan bilgiler olarak görülmektedir. Burada dikkat çeken nokta ise akredite olunan örgütlere ilişkin sadece bir hastanenin link vermiş olması güvenle ilgili ortaya konan eksiklik olarak ifade edilebilmektedir.

Tablo 4: Genel Riskler

\begin{tabular}{|l|c|}
\hline Öğeler & - \\
\hline Ameliyat sonrası bakım & 2 \\
\hline Prosedürsel riskler & 1 \\
\hline Yasal müracaatlar & - \\
\hline Olumsuz/zor durumlar & \\
\hline
\end{tabular}

Kurumsal web sitelerinde hastaların karşılaşabilecekleri genel risklerle ilgili olarak sadece iki web sitesinin hastanenin prosedürlerle ve yasal müracaatlarıyla ilgili 
bilgi verdiği anlaşılmaktadır. Diğer taraftan ameliyat sonrası bakım ve olumsuz ya da zor durumlarla ilgili açıklayıcı net bilgilerin web sitelerinde bulunmaması, genel riskler başı̆̆ı altında eksik görülen bir başka konudur.

Tablo 5: Ödeme veya Maddi Bilgiler

\begin{tabular}{|l|c|}
\hline Öğeler & \\
\hline Uluslararası sigorta seçenekleri & 11 \\
\hline Nakit ön ödemeler & - \\
\hline Finansman seçenekleri & - \\
\hline
\end{tabular}

Hastaların ödeme ve maddi bilgi edinmeleri konusunda 11 web sitesinde uluslararası sigorta seçeneklerinin yer aldığı görülmektedir. Bunun yanında nakit ön ödemeler ve finansman seçeneklerine ilişkin bilgilerin hiçbir web sitesinde yer almadığı anlaşılmaktadır. Özellikle ülke dışından hasta kabul eden hastanelerin ödemeler konusunda hastaların daha aydınlatıcı bilgiye gereksinimlerine yönelik web sitelerinden bilginin tam anlamıyla alınamaması dikkat çekmektedir.

Tablo 6: Genel Bilgi

\begin{tabular}{|l|c|}
\hline Öğeler & 12 \\
\hline Karşılama ve misyon açıklamaları & 5 \\
\hline Sıķa sorulan sorular & 1 \\
\hline Sunulan hizmetlerin lokasyonunun gösterimi & 14 \\
\hline Hakkımızda & \\
\hline
\end{tabular}

Genel Bilgi başlığı altında 15 web sitesinin 14'ünde hakkımızda bölümü yer alırken, 12 web sitesi karşılama ve misyon açıklamalarını hastalarıyla paylaşmaktadır. Sıkça sorulan sorular başlığının sadece 5 web sitesinde yer alması ve sunulan hizmetlere ilişkin lokasyon gösteriminin 1 web sitesinde bulunması da bilgilendirmede göze çarpan bir başka ayrıntıdır.

Tablo 7: Web Sitelerindeki Görseller

\begin{tabular}{|l|c|}
\hline Öğeler & 15 \\
\hline Hastanenin dış görünüşü & 14 \\
\hline Teşhis veya görüntüleme cihazları & 14 \\
\hline Hastane/tesis logosu & 4 \\
\hline Turist/seyahat görüntüleri & 8 \\
\hline Prosedürlerin seyri & 12 \\
\hline Hekimlerle ziyaret & 8 \\
\hline İyileşme sonrası & 3 \\
\hline Hemşirelik bakımı & 15 \\
\hline Personel fotoğrafları & 14 \\
\hline Hastanenin içindekiler & 13 \\
\hline Haritalar & \\
\hline
\end{tabular}

15 web sitesindeki ortaya konan görsellere ilişkin bir özet yapmak gerekirse 15 web sitesinin tamamının hastanenin dış görünüşüne yer verdiği, 15 web sitesinde personel fotoğraflarının bulunduğu, 14 web sitesinde ise teşhis veya görüntüleme cihaz görüntüleri ile hastane logosunun yer aldığı, 13 web sitesinde harita görsellerinin kullanıldığı, 12 web sitesinde hekimlerle ziyarete ilişkin görsellere yer verildiği, 8 web sitesinde ise hastanedeki prosedürler ve iyileşme sonrasına ilişkin görsel özetlerin yer aldığı görülmektedir. En az dikkat çeken görselin ise hemşirelik bakımının olduğu anlaşılmaktadır. 


\subsection{Facebook Sosyal Medya Hesaplarına İlişkin Bulgular}

Araştırma kapsamında yer alan hastanelerden altısının Türkçe dışında İngilizce Facebook hesaplarının da bulunduğu belirlenmiştir. Analiz, hastanelerin 2015 yılının Eylül (dâhil) ayına kadar yaptıkları tüm paylaşımlara yöneliktir. 2 hastane 2015, 1 hastane 2014, 1 hastane 2013, 1 hastane 2012, 1 hastane ise 2011 yılından beri İngilizce Facebook hesaplarını kullanmaktadır.

Aşağıda yer alan tabloda altı hastanenin Türkçe ve İngilizce Facebook sayfalarının beğeni sayısı ile İngilizce hesaplarından paylaştıkları içerik sayıları gösterilmektedir.

Tablo 8: Hastanelerin Facebook Beğeni Sayıları

\begin{tabular}{|c|c|c|c|}
\hline Hastane Adı & $\begin{array}{ll}\begin{array}{l}\text { Beğeni } \\
\text { (Uluslararası) }\end{array} & \text { Sayısı } \\
\end{array}$ & $\begin{array}{ll}\text { Beğeni } & \text { Sayısı } \\
\text { (Türkiye) } & \\
\end{array}$ & $\begin{array}{l}\text { Toplam İçerik Sayısı ve } \\
\text { Yılı (Uluslararası) }\end{array}$ \\
\hline A & 193.349 & 324.052 & $\begin{array}{l}\text { Toplam: } 189 \\
87(2015) \\
30(2014) \\
53(2013) \\
19(2012) \\
\end{array}$ \\
\hline B & 43.746 & 72.388 & $\begin{array}{l}\text { Toplam: } 55 \\
55(2015)\end{array}$ \\
\hline C & 1.622 & 41.301 & $\begin{array}{l}\text { Toplam: } 83 \\
4(2015) \\
6(2014) \\
63(2013) \\
7(2012) \\
3(2011) \\
\end{array}$ \\
\hline D & 6.065 & 34.685 & $\begin{array}{l}\text { Toplam: } 529 \\
215(2015) \\
404(2014)\end{array}$ \\
\hline$E$ & 3.966 & 180.191 & $\begin{array}{l}\text { Toplam: } 242 \\
65(2015) \\
92(2014) \\
85(2013)\end{array}$ \\
\hline$F$ & 379 & 345.472 & $\begin{array}{l}\text { Toplam: } 248 \\
248(2015)\end{array}$ \\
\hline
\end{tabular}

Hastanelerin Facebook sosyal medya hesaplarında toplam 1346 adet içerik paylaştıkları saptanmıştır. Bu içeriklerin konularına göre analizi yapıldığında elde edilen dağılım aşağıdaki tabloda gösterilmektedir.

Tablo 9: Hastanelerin Facebook İçeriklerinin Konuları

\begin{tabular}{|c|c|c|c|c|c|c|c|c|c|}
\hline $\begin{array}{l}\text { Hastane } \\
\text { Adı }\end{array}$ & $\begin{array}{l}\text { Hastalık } \\
\text { Bilgilendirme }\end{array}$ & $\begin{array}{l}\text { Sağlıklı } \\
\text { Yaşam } \\
\text { Öneriler }\end{array}$ & $\begin{array}{l}\text { Hastanenin } \\
\text { Hizmetleri- } \\
\text { Olanakları }\end{array}$ & $\begin{array}{l}\text { Hastalık } \\
\text { Bilgilendirme } \\
\& \\
\text { Hastanenin } \\
\text { Hizmetleri- } \\
\text { Olanakları } \\
\end{array}$ & $\begin{array}{l}\text { Hasta } \\
\text { Haberleri- } \\
\text { Hikayeleri }\end{array}$ & $\begin{array}{l}\text { Hastane } \\
\text { Tanıtım } \\
\text { Haberleri } \\
\text { Görselleri- } \\
\text { Videoları }\end{array}$ & $\begin{array}{l}\text { Bilimsel } \\
\text { Toplantılar } \\
\text { Düzenleme } \\
\text { Toplantılara } \\
\text { Katılım }\end{array}$ & $\begin{array}{l}\text { Özel } \\
\text { Gün } \\
\text { Mesajlar }\end{array}$ & $\begin{array}{l}\text { Profil } \\
\text { Kapak } \\
\text { Fotoğrafı } \\
\text { Güncelleme } \\
\text { \& } \\
\text { Diğer } \\
\end{array}$ \\
\hline$A$ & 37 & 26 & 38 & 13 & 20 & 33 & 8 & 9 & 5 \\
\hline B & - & 1 & 38 & 6 & 4 & 3 & - & - & 1 \\
\hline$C$ & 12 & 2 & 19 & 2 & 3 & 42 & 1 & 1 & 1 \\
\hline D & 85 & 47 & 90 & 12 & 23 & 200 & 54 & 12 & 6 \\
\hline$E$ & 60 & 25 & 26 & 12 & 20 & 58 & 12 & 24 & 5 \\
\hline$F$ & 52 & 91 & 27 & 1 & 1 & 32 & 18 & 7 & 19 \\
\hline $\begin{array}{c}\text { Toplam: } \\
1346\end{array}$ & 246 & 192 & 238 & 46 & 71 & 368 & 93 & 53 & 37 \\
\hline
\end{tabular}


Araştırma sonuçlarının toplamına bakıldığında en fazla içerik paylaşımı hastane tanıtım haberleri, görselleri ve videoları ile ilgili yapılmıştır. Ancak burada üzerinde durulması gereken nokta, bir hastanenin bu konuda çok fazla paylaşım yapması nedeniyle sayının artmış olmasıdır. Hastaneler kendi paylaşımlarına göre tek tek değerlendirildiğinde bir hastanenin en fazla hastalık bilgilendirme ve hastanenin hizmetleri/olanakları konusunda; bir hastanenin verdikleri hizmetler/olanaklar konusunda; iki hastanenin tanıtım haberleri/görselleri/videoları konusunda bir hastanenin hastalık bilgilendirme konusunda, bir hastanenin ise sağlıklı yaşam önerileri konusunda paylaşım yaptıkları saptanmıştır. En az paylaşım ise kapak fotoğrafı güncelleme gibi diğer başlığı altında değerlendirilebilecek içeriklere ilişkin olmuştur.

Hastalık Bilgilendirme başığı altında hastaneler çeşitli hastalıklar ve tedavileri konusunda içerik paylaşmaktadır. Sağlıklı yaşam önerileri konusunda beslenme önerileri, spora teşvik, zararlı tüketim, depresyondan kaçınma, kalp sağlığını koruma gibi içerikler paylaşmıştır. Hastanenin hizmetleri-olanakları başlığı altında hastanenin sahip oldukları hizmetler, teknolojik olanakları, tedavi süreçleri gibi konularda içerik paylaşmıştır. Hastalık bilgilendirme \&hastanenin hizmetleri-olanakları başlığı altında hastanelerin öncelikle hastalık hakkında bilgi verip ardından sundukları hizmetleri ve tedavileri aktardıkları içerikler bulunmaktadır. Hasta haberleri-hikayeleri başlığı altında hastanede tedavi gören hastaların hikayeleri, hastaların ve yakınlarının hastane hakkındaki görüşleri yer almaktadır. Bunun yanında hastalarla yapılan röportajların videolarının ve hasta fotoğraflarının paylaşıldığı görülmektedir. Hastane tanıtım haberleri-görselleri-videoları başlığında hastanenin temel tanıtım mesajları, akredite belgesine sahip olmaları, amaçları ve değerleri, hastanelere yapılan ziyaretler, düzenlenen etkinlikler, kalite gibi konularda hastaneye ilişkin temel mesajlar ve çeşitli etkinlik haberleri verilmektedir. Bilimsel toplantılar düzenleme-toplantılara katılım başlığında hastanelerin düzenledikleri bilimsel toplantılar, bilimsel etkinliklere katılım, yayınlanan bilimsel çalışmalar gibi içerikler paylaşılmaktadır. Özel gün mesajları başıı̆ı altında anneler günü, babalar günü, tıp bayramı, hemşireler haftası, yeni yıl, bayram gibi kutlamaların yanında dünya kanser günü, kalp günü gibi günlerde mesajlar yayınlamıştır. Profil kapak fotoğrafı güncelleme \& diğer başlığı altında fotoğraf güncellemelere ve bunun dışında çeşitli mesajlara yer verilmiştir.

Araştırma kapsamındaki hastanelerin Facebook kullanımları öngörüler açısından değerlendirildiğinde, kullanıcıların çok fazla öneride bulunmadıkları saptanmıştır. Bunun yerine genelde takdir ve teşekkürde bulundukları yorumlar yaptıkları görülmektedir. Ancak bir hastanenin İngilizce Facebook hesabında paylaşılan Türkçe içeriğin bulunduğu bir linke kullanıcılardan biri şöyle bir yorumda bulunmuştur: "Sosyal medya yönetimi konusunda çok kötüsünüz. İngilizce olması gereken sayfada Türkçe paylaşımlar olmaz". Bu yorumdan sonra da hastane Türkçe bir paylaşımda bulunmamıştır.

Araştırma kapsamındaki hastanelerden birinin uluslararası Facebook sayfası 193.349 gibi yüksek bir beğeni sayısına sahiptir. Bu hastanenin içeriklerinin de diğerlerine nazaran daha fazla beğeni aldığı ve paylaşıldığı görülmektedir. 
Tablo 10: Hastanelerin Paylaştıkları En Fazla Beğenilen İçerikler

\begin{tabular}{|c|c|}
\hline Hastane Adı & İçerik \\
\hline A & $\begin{array}{ll}- & \text { Arda Turan tedavi haberi (3962 beğeni) } \\
\text { - } & \text { Anne babalar için yaz tatili önerileri (3868 beğeni) } \\
\text { - } & \text { Sağlık durumunuzla ilgili farklı fikir alın ( } 3592 \text { beğeni) }\end{array}$ \\
\hline B & $\begin{array}{ll} & \text { Cerrahi merkezi haberi ( } 6870 \text { beğeni) } \\
\text { - } & \text { Prostat kanseri ile ilgili merkez haberi (6066 beğeni) } \\
\text { - } & \text { Saç ekim kliniği (3773 beğeni) }\end{array}$ \\
\hline C & $\begin{array}{ll} & \text { Karaciğer nakli doktorunun videosu (14 beğeni) } \\
\text { - } & \text { Bir hastanın kalp nakli hikâyesi (12 beğeni) } \\
\text { - } & \text { Klinik bilgisi ( } 11 \text { beğeni) } \\
\end{array}$ \\
\hline $\mathrm{D}$ & $\begin{array}{ll} & \text { Saç ekim paketi-hizmetler ve ücreti (3378 beğeni) } \\
\text { - } & \text { Lasik surgery paketi (2252 beğeni) } \\
\text { - } \quad \text { Implant paketi (1258 beğeni) }\end{array}$ \\
\hline$E$ & $\begin{array}{ll}- & \text { Kurumsal bowling turnuvası ( } 26 \text { beğeni) } \\
\text { - } & \text { Hastaneye ziyaret ( } 25 \text { beğeni) } \\
\text { - } & \text { Bir hastanın meme kanseri hikayesi ( } 17 \text { beğeni) } \\
\end{array}$ \\
\hline $\mathrm{F}$ & $\begin{array}{ll}- & \text { Organ nakli merkezi (27 beğeni) } \\
\text { - } & \text { Hastane ödülü haberi ( } 23 \text { beğeni) } \\
\text { - } & \text { Bir hastanın karaciğer nakli hikayesi (22 beğeni) } \\
\end{array}$ \\
\hline
\end{tabular}

Yukarıda yer alan tabloda belirtildiği gibi kullanıcılar ünlülerin tedavisi, yeni bir merkezin açılışı, bowling turnuvası gibi birbirinden farklı içerikleri beğenmiştir. Bazı hastanelerin içeriklerinin yüksek beğenilerine sahip olduğu söylenebilmektedir.

Tablo 11: Hastanelerin İçeriklerinden En Fazla Paylaşılanlar

\begin{tabular}{|c|c|}
\hline Hastane Adı & İçerik \\
\hline A & $\begin{array}{ll}\text { - } & \text { Hastanenin tanıtımı ile ilgili içerik (39 paylaşım) } \\
\text { - } & \text { Arda turan tedavi haberi (20 paylaşım) } \\
\text { - } & \text { Tümörlerin tedavisinde kullanılan teknoloji (19 paylaşım) } \\
\end{array}$ \\
\hline B & $\begin{array}{ll}- & \mathrm{JCl} \text { akredite haberi (42 paylaşım) } \\
\text { - } & \text { Prostat kanseri ile ilgili merkez haberi (17 paylaşım) } \\
\text { - } & \text { Kısırlık tedavi merkezi (7 paylaşım) } \\
\end{array}$ \\
\hline $\mathrm{C}$ & - $\quad$ Beğenilerin dağılımı benzer olduğu için sıralamaya alınmamıştır. \\
\hline $\mathrm{D}$ & $\begin{array}{ll}\text { - } & \text { Kliniklerdeki takımın ve uluslararası bölümlerin büyümesi (4 paylaşım) } \\
\text { - } & \text { Radyoloji bölümü ve ileri teknolojiyle donatılmış tıbbi cihazlar (4 paylaşım) } \\
\text { - } & \text { Saç ekim paketi-hizmetler ve ücreti (3 paylaşım) } \\
\text { - } & \text { Robotik cerrahinin avantajları (3 paylaşım) }\end{array}$ \\
\hline $\mathrm{E}$ & $\begin{array}{ll}\text { - } & \text { Onkoloji checkup paketi (4 paylaşım) } \\
\text { - } & \text { Cardiogoniometry metodu (3 paylaşım) } \\
\text { - } & \text { Başka kurumla protokol (3 paylaşım) } \\
\text { - } & \text { Uluslararası hasta merkezi tanıtımı (3 paylaşım) } \\
\text { - } & \text { Ünlü sporcunun checkup yaptırması (3 paylaşım) }\end{array}$ \\
\hline $\mathrm{F}$ & $\begin{array}{ll}\text { - } & \text { Organ nakli merkezi (92 paylaşım) } \\
\text { - } & \text { Bir hastanın karaciğer nakli hikayesi (5 paylaşım) } \\
\text { - } & \text { Birlikte çalışılan uluslararası sigorta şirketleri (3 paylaşım) } \\
\text { - } & \text { Yeni yıl kutlaması (3 paylaşım) }\end{array}$ \\
\hline
\end{tabular}

Yukarıda yer alan tabloda belirtilenlerden yola çıkarak hastanelerin içeriklerinin kullanıcılar tarafından çok fazla paylaşılmadığı söylenebilmektedir. Dağılıma bakıldığında kullanıcıların farklı konulardaki içerikleri paylaştığı görülmektedir. 
Tablo 12: Hastanelerin İçeriklerinden En Fazla Yorumlananlar

\begin{tabular}{|c|cl|}
\hline Hastane Adı & & \multicolumn{1}{c|}{ İçerik } \\
\hline A & $\bullet$ & Sigaranın zararları bilgilendirme (14 yorum) \\
& $\bullet$ & $\begin{array}{l}\text { Arda turan tedavi haberi (10 yorum) } \\
\text { Hasta hikâyesi (10 yorum) }\end{array}$ \\
\hline & $\bullet$ & $\begin{array}{l}\text { Prostat kanseri ile ilgili merkez haberi (22 yorum) } \\
\text { B }\end{array}$ \\
& • & $\begin{array}{l}\text { Saç ekim kliniği (20 yorum) } \\
\text { Hematoloji bölümü ve kök hücre nakil merkezi (10 yorum) }\end{array}$ \\
\hline C & $\bullet$ & Yluslararası hasta hizmetleri (10 yorum) \\
\hline D & $\bullet$ & Saç ekim paketi-hizmetler ve ücreti (2 yorum) \\
\hline E & $\bullet$ & Bilimsel etkinlik (2 yorum) \\
\hline F & $\bullet$ & Yorumların dağılımı benzer olduğu için sıralamaya alınmamıştır. \\
\hline & & Yorumların dağılımı benzer olduğu için sıralamaya alınmamıştır. \\
\hline
\end{tabular}

Hastanelerin paylaştıkları içeriklere kullanıcılar tarafından yapılan yorumların oldukça az olması dikkat çekicidir. Yüksek Facebook beğenisine sahip olan hastanelerde de durumun pek farklı olmadığı göze çarpmaktadır.

\subsection{Twitter Sosyal Medya Hesaplarına İlişkin Bulgular}

Araştırma kapsamında yer alan hastanelerden beşinin Türkçe dışında İngilizce Twitter hesaplarının da bulunduğu belirlenmiştir. Analiz, hastanelerin 2015 yılının Eylül (dahil) ayına kadar yaptıkları tüm paylaşımlara yönelik yapılmıştır. Aşağıda yer alan tabloda beş hastanenin Türkçe ve İngilizce Twitter sayfalarının tweet, takip edilme, takipçi sayısı ve favorileri gösterilmektedir. Aşağıda yer alan tabloda belirtildiği gibi İngilizce Twitter sayfasını 1 hastane 2011, 2 hastane 2013, 1 hastane 2014 ve 1 hastane 2015 yılından beri kullanmaktadır. İngilizce Twitter sayfasına sahip olan hastanelerin Türkçe Twitter sayfalarına bakıldığında ise 2 hastanenin 2009 yılından, 2 hastanenin 2011 ve 1 hastanenin ise 2012 yılından beri Twitter hesaplarını kullandıkları görülmektedir.

Tablo 13: Twitter Hesabına Sahip Hastaneler (İngilizce-Türkçe)

\begin{tabular}{|c|c|c|c|c|c|}
\hline Hastane Adı & $\begin{array}{l}\text { Başlangıç } \\
\text { (Ing) (Tr) }\end{array}$ & $\begin{array}{c}\text { Tweetler } \\
\text { (Ing) (Tr) }\end{array}$ & $\begin{array}{c}\text { Takip Edilme } \\
\text { (Ing) } \\
\text { (Tr) }\end{array}$ & $\begin{array}{c}\text { Takipçi } \\
\text { (Ing) } \\
\text { (Tr) }\end{array}$ & $\begin{array}{c}\text { Favori } \\
\text { (Ing) } \\
\text { (Tr) }\end{array}$ \\
\hline B & $\begin{array}{l}2015 \\
2011\end{array}$ & $\begin{array}{c}1 \\
610\end{array}$ & - & $\begin{array}{c}- \\
12.700\end{array}$ & 9 \\
\hline C & $\begin{array}{l}2011 \\
2011\end{array}$ & $\begin{array}{c}36 \\
640\end{array}$ & $\begin{array}{c}16 \\
101\end{array}$ & $\begin{array}{l}199 \\
177\end{array}$ & - \\
\hline D & $\begin{array}{l}2013 \\
2012\end{array}$ & $\begin{array}{c}661 \\
4.065\end{array}$ & $\begin{array}{l}301 \\
240\end{array}$ & $\begin{array}{c}1175 \\
10.300\end{array}$ & $\begin{array}{l}697 \\
137\end{array}$ \\
\hline$E$ & $\begin{array}{l}2013 \\
2009\end{array}$ & $\begin{array}{c}242 \\
21.300\end{array}$ & $\begin{array}{c}41 \\
361\end{array}$ & $\begin{array}{c}159 \\
10.200\end{array}$ & $\begin{array}{c}- \\
34\end{array}$ \\
\hline$F$ & $\begin{array}{l}2014 \\
2009\end{array}$ & $\begin{array}{c}144 \\
3.310\end{array}$ & $\begin{array}{c}86 \\
3\end{array}$ & $\begin{array}{c}111 \\
38.300\end{array}$ & $\begin{array}{c}38 \\
517\end{array}$ \\
\hline
\end{tabular}

Hastanelerin İngilizce Twitter hesaplarında toplam 1084 adet içerik paylaştıkları saptanmıştır. Bu içeriklerin konularına göre analizi yapıldığında elde edilen dağılımın Facebook paylaşımlarıyla çok büyük oranda benzeşmesi nedeniyle dağılımın da Facebook analizi ile paralellik gösterdiği anlaşılmaktadır. 
Tablo 14: Hastanelerin En Fazla Retweet Yapılan İçerikleri

\begin{tabular}{|c|c|}
\hline Hastane Adı & İçerik \\
\hline $\mathrm{B}$ & - \\
\hline C & $\begin{array}{ll}- & \text { Bir hastanın tedavi hikayesi (2 retweet) } \\
\text { - } & 500 . \text { karaciğer naklinin başarıyla gerçekleştirilmesi (2 retweet) }\end{array}$ \\
\hline D & $\begin{array}{ll}- & \text { Saç ekim paketi-hizmetler ve ücreti (10 retweet) } \\
\text { - } & \text { Kök hücre Araştırma ve Uygulama Merkezi haberi (8 retweet) } \\
\text { - } & \text { Hastane tanıtımı (7 retweet) }\end{array}$ \\
\hline $\mathrm{E}$ & $\begin{array}{ll}\text { - } & \text { Dünya Kanser Günü Bilgilendirme (1 retweet) } \\
\text { - } & \text { Hastane tanıtımı (1 retweet) }\end{array}$ \\
\hline $\mathrm{F}$ & - $\quad$ Hastaneye uluslararası ödül verilmesi (4 retweet) \\
\hline
\end{tabular}

Hastanelerin İngilizce Twitter paylaşımlarına bakıldığında, paylaşım sayısının İngilizce Twitter sayfasına sahip olan hastanelerin Türkçe Twitter paylaşımlarından sayı olarak oldukça geri kaldığı görülmektedir. Aynı şekilde Türkçe Twitter sayfalarındaki takip sayısının da İngilizce Twitter sayfalarının çok üzerinde olduğu anlaşılmaktadır. Sadece bir hastanenin Türkçe ve İngilizce Twittere giriş tarihlerinin aynı olduğu diğer dört hastanenin ise önce Türkçe Twitter kullanıcısı olup, Türkçe Twitter sayfasına sahip olduktan 1 ile 4 yıl arasında değişen sürelerde İngilizce Twitter kullanıcısı olmaları dikkat çeken bir başka ayrıntıdır. Diğer taraftan Türkçe Twitter sayfalarında düzenli güncelleme yapıldığı anlaşılırken 2012 tarihinden bu yana Ingilizce Twitter sayfasını güncelleme yapmayan bir hastanenin olduğu da görülmektedir.

\section{Tartışma ve Sonuç}

$\mathrm{Bu}$ araştırmada İstanbul'da bulunan $\mathrm{JCl}$ akreditasyonuna sahip hastanelerin sağlık turizmi kapsamında dijital iletişimi kullanmalarına yönelik önemli bulgular elde edilmiştir. Kurumsal web siteleri açısından değerlendirildiğinde, genel beklentileri karşılamakla birlikte prosedürler, karşılaşılacak olumsuz durumlar ve finansmanla ilgili bilgilerin eksikliği dikkat çekmektedir. Kurumsal web sitelerinin görsellerinin bazılarında çözünürlük ve kalitenin gözden geçirilmesi, kullanılan yabancı dilin daha anlaşılır olması ile web sitelerinin etkinliğinin hastaneler açısından arttırılacağına inanılmaktadır. Mason ve Wright (2011) tarafından medikal turizm açısından web sitelerinin incelenmesine yönelik gerçekleştirilen araştırmada, web sitelerinde 'medikal uygulamaların faydaları' hakkında detaylı bilgi sunulduğu ancak 'riskler ve uygulamaların güvenilirliği' konularından çok az söz edildiği saptanmıştır. Birdir ve Buzcu (2014) tarafından $\mathrm{JCl}$ akreditasyonuna sahip olan sağlık kuruluşlarının web sitelerine yönelik yapılan araştırmada 'yabancı dillerde hastanelerin web sitelerine girme, hastanelerin konumları ve iletişim konularında bilgi verme, anlaşmalı kurumların sunulması, internet üzerinden randevu olanaklarının bulunması' oranlarının yüksek olduğu ancak 'hizmetlerin ücretleri ve maliyetleri' konusunda bilgi akışının olmadığı bulgusuna ulaşılmıştır. Sonuçlar, bu çalışmada elde edilen bulgularla benzerlik taşımaktadır.

Sosyal medyada en çok kullanılan Facebook hesapları incelendiğinde, bazı konular hakkındaki içeriğin daha fazla ön plana çıktığı görülmüştür. Ancak hastanelerin genelinin bu sosyal medya aracında birçok içerik paylaştığı söylenebilir. Facebook kullanımı konusundaki temek eksiklik, içerik paylaşımından ziyade kullanıcılarla etkileşim sağlanamıyor oluşudur. Nitekim bazı hastanelerin paylaştıkları içeriklerin hiç beğeni veya yorum almadığı saptanmıştır. Dolayısıyla hastanelerin bu konudaki eksikliği gidermesi önerilmektedir. İngilizce Twitter kullanımında dikkati çeken ise retweet yapılarak paylaşımların geniş kitlelere ulaşmasının hedeflendiği bu iletişim 
kanalının çok büyük bir benzerlikle Facebook paylaşımlarının bu platformda paylaşılması nedeniyle retweet sayısının neredeyse yok denecek sayıda olmasına neden olduğu düşünülmektedir. Bu açıdan bakıldığında Twitter kullanımının sosyal medyada hangi amaç ve beklenti ile kullanıldığının irdelenmesi ve Facebook-Twitter karşılaştırmasının hastaneler açısından tekrar gözden geçirilmesi gerektiği anlaşılmaktadır. Bu açıdan atılan tweetlerin Facebookta kullanılan paylaşımlar olması nedeniyle Facebook paylaşımında ortaya konan dokuz boyutlu paylaşım değerlendirmeleri, Twitter için de aynı geçerliliği göstermektedir.

Araştırma bulguları genel olarak değerlendirildiğinde, dijital iletişimden daha çok bilgilendirme amaçlı yararlanıldığı söylenebilmektedir. Bilgilendirme, sağlık turizmi kapsamında farklı yerlerde ikamet eden turistlerin sunulan hizmetin farkında olması açısından önem arz etmektedir. Ancak burada üzerinde durulması gereken dijital iletişimin, geleneksel iletişim kanallarından çok daha fazla etkileşime olanak veren yapısıdır. Kullanıcıların sosyal medya hesaplarını beğenmesi veya takip etmesi yeterli görülmemelidir. Kullanıcıların yorum yaptıkları, içerikleri paylaştıkları ve hatta hastanelerden birlikte içerik üretim sürecinin bir parçası olmaları sağlanabilmelidir.

Hastanelerin paylaştıkları içeriğe kullanıcıların neden ortak olmadıkları veya burada bir diyaloğun neden oluşmadığı konusunda çalışmalar yürütülmesi, dijital kanalların daha etkili kullanımının yolunu açacaktır. Sağlık turizmi kapsamında iletişim, her şeyden önce güven sağlamayı zorunlu kılar. Kullanıcılarla etkileşime dayalı bir diyaloğun oluşması, soruların cevaplanması ve kaygıların giderilmesi açısından temel bir gerekliliği yerine getirmektedir. Dolayısıyla sağlık turizmi açısından dijital iletişim kanallarının kullanımının temelinde, kullanıcılarla etkileşim oluşturabilmek yatmaktadır.

Sağlık turizmi kapsamında sosyal medyanın nasıl kullanıldığına ilişkin araştırmalar henüz yeterince dikkat çekmese de, sosyal medyanın turizme etkileri çeşitli araştırmalarda ortaya konulmuştur. Sosyal medyanın turistlerin bilgi arayışlarında, seyahat deneyimlerinin paylaşılmasında, destinasyonların pazarlanmasında nası kullanıldığı gibi sorulara araştırmacılar tarafından yanıt aranmıştır (Királ'ová ve Pavlíčeka, 2015; Munar ve Jacobsen, 2014; Xiang ve Gretzel, 2010; Miguéns vd., 2008).

$\mathrm{Bu}$ çalışmada yalnızca $\mathrm{JCl}$ akreditasyon belgesine sahip İstanbul'da faaliyet gösteren hastanelere yönelik içerik analizi yöntemi kullanılarak bir araştırma gerçekleştirilmiştir. Gelecek çalışmalarda farklı şehirlerde bulunan ve/veya JCI akreditasyonuna sahip olmayan hastanelere yönelik araştırmalar yürütülmesi, daha büyük bir resmin ortaya konulmasını sağlayacaktır. Bunun yanında derinlemesine görüşme ve anket gibi araştırma yöntemleri kullanılarak, daha geniş bulgular elde edilebilir.

\section{Kaynakça}

Aydın, G. ve Aydın, B. K. (2015), 'Dünyada ve Türkiye'de Sağlık Turizmi Pazarlama Uygulamaları ve Karşılaştırmalı Durum Analizi', Pazarlama ve Pazarlama Araştırmaları Dergisi, 16, ss. 1-21.

Birdir, K. ve Buzcu, Z. (2014), 'JCl Akreditasyon Belgesine Sahip Olan Sağlık Kuruluşlarının WEB Sitelerinin Medikal Turizm Açısından Değerlendirilmesi', Çă̆ Üniversitesi Sosyal Bilimler Dergisi, 11(1), ss. 1-19.

Brucks, M. (1985), 'The Effects of Product Class Knowledge on Information Search Behavior', Journal of Consumer Research, 12(1), ss. 1-16. 
Carrera, P. M. ve Bridges, J. F. P. (2006), 'Globalization and Healthcare: Understanding Health and Medical Tourism', Expert Review of Pharmacoeconomics \& Outcomes Research, 6 (4), ss. 447-454.

Chon, K. S. (1991), 'Tourism Destination Image Modification Process: Marketing Implications', Tourism Management, 12(1), ss. 68-72.

Crooks, V. A., Turner, L., Snyder, J., Johnston, R., Kingsbury, P. (2011), 'Promoting Medical Tourism to India: Messages, Images, and the Marketing of International Patient Travel', Social Science \& Medicine, 72, ss. 726-732.

Dodd, T. H., Laverie, D. A., Wilcox, J. F. ve Duhan, D. F. (2005), 'Differential Effects of Experience, Subjective Knowledge, and Objective Knowledge on Sources of Information Used in Consumer Wine Purchasing', Journal of Hospitality \& Tourism Research, 29(1), ss. 3-19.

Edinsel, S. ve Adıgüzel, O. (2014), 'Türkiye'nin Sağlık Turizmi Açısından Son Beş Yıldaki Dünya Ülkeleri İçindeki Konumu ve Gelişmeleri', Çankırı Karatekin Üniversitesi İktisadi ve Idari Bilimler Fakültesi Dergisi, 4(2), ss.167-190.

Eikelmann, S., Hajj, J. ve Peterson, M. (2008), 'Opinion piece: Web 2.0: Profiting from the Threat', Journal of Direct, Data and Digital Marketing Practice, 9(3), 293-295.

Geriatri,http://www.turkey-healthtourism.com/GERIATRI-_c_d_36.htm (01.02.2016).

Govers, R. ve Go, F. M. (2003), 'Deconstructing Destination Image in the Information Age', Information Technology and Tourism, 6(1), ss. 13-29.

Gülen, K. G. ve Demirci, S. (2010), 'Türkiye'de Sağlık Turizmi Sektörü', İstanbul Ticaret Odası Yayınları, Sektörel Etütler ve Araştırmalar, Yayın No:2011-39, İstanbul, http://www.ito.org.tr/itoyayin/0026604.pdf (06.01.2016).

Hennig-Thurau, T., Walsh, G. \& Walsh, G. (2015), 'Electronic Word-of-Mouth: Motives for and Consequences of Reading Customer Articulations on the Internet', International Journal of Electronic Commerce, 8(2), ss. 51-74.

Hvass, K. A ve Munar, A. M. (2012), 'The Takeoff of Social Media in Tourism', Journal of Vacation Marketing, 18(2), ss. 93-103.

Kietzmann, J. H., Hermkens, K, McCarthy, I.P. ve Silvestre, B.S. (2011), 'Social media? Get serious! Understanding the Functional Building Blocks of Social Media', Business Horizons, 54(3), ss. 241-251.

Királ'ová, A. ve Pavlíčeka, A. (2015), 'Development of Social Media Strategies in Tourism Destination, International Conference on Strategic Innovative Marketing', IC-SIM 2014, September 1-4, 2014, Madrid, Spain.

Klenosky, D. B. ve Gitelson, R. E. (1998), 'Travel Agents' Destination Recommendations', Annals of Tourism Research, 25(3), ss. 661-674.

Leung, D., Law, R., van Hoof, H. ve Buhalis, D. (2013), 'Social Media in Tourism and Hospitality: A Literature Review', Journal of Travel \& Tourism Marketing, 30(1-2), ss. 3-22.

Litvin, S. W., Goldsmith, R. E. ve Pan, B. (2008), 'Electronic Word-Of-Mouth in Hospitality and Tourism Management' Tourism Management, 29, ss. 458-468.

MacKay, K. J. ve Fesenmaier, D. R. (2000), 'An Exploration of Cross-Cultural Destination Image Assessment', Journal of Travel Research, 38 (4), ss. 417423.

MacReady, N. (2007), 'Developing Countries Court Medical Tourists', The Lancet, 369 (9576), ss. 1849-1850. www.thelancet.com, (06.07.2015).

Mason, A. ve Wright, K. B. (2011), 'Framing Medical Tourism: An Examination of Appeal, Risk, Convalescence, Accreditation, and Interactivity in Medical Tourism Web Sites', Journal of Health Communication, 16(2), ss. 163-177.

Miguéns, J., Baggio, R. ve Costa, C. (2008). 'Social Media and Tourism Destinations: TripAdvisor Case Study', IASK ATR2008 (Advances in Tourism Research 2008), May 26-28 2008, Aveiro, Portugal. 
Morgan, N., Pritchard, A. ve Pride, R. (2011), 'Tourism Places, Brands, and Reputation Management' İçinde N. Morgan, A. Pritchard ve R. Pride (Editörler), Destination Brands - Managing Place Reputation, ss. 3-21, Elsevier ButterworthHeinemann.

Muğla İli Turizm Sektörünün Uluslararası Rekabetçilik Analizi, http://www.fto.org.tr/DB_Image/29/99/Mu\%C4\%9Fla\%20Rekabet\%C3\%A7ilik\% 20Analizi.pdf (01.02.2016).

Mulec, I. (2010), 'Promotion as a Tool in Sustaining the Destination Marketing Activities', Turizam, 14(1), ss. 13-21.

Munar, A. M. ve Jacobsen, J.Kr. S. (2014), 'Motivations for Sharing Tourism Experiences through Social Media' Tourism Management, 43, ss. 46-54.

Neiger, B. L., Thackeray, R, Van Wagenen, S.A., Hanson, C.L., West, J. H. , Barnes M.D. ve Fagen, M. C. (2012), 'Use of Social Media in Health Promotion: Purposes, Key Performance Indicators, and Evaluation Metrics', Health Promotion Practice, 13(2), ss.159-164.

Özsarı, S. H. ve Karatana, Ö. (2013), 'Sağlık Turizmi Açısından Türkiye'nin Durumu', Journal Kartal TR, 24(2), ss. 136-144.

Pabel, A ve Prideaux, B. (2015), 'Social Media Use in Pre-Trip Planning By Tourists Visiting A Small Regional Leisure Destination', Journal of Vacation Marketing.

Rao, A. R. ve Monroe, K. B. (1988), 'The Moderating Effect of Prior Knowledge on Cue Utilization in Product Evaluations', The Journal of Consumer Research, 15(2), ss. 253-264.

Sağıık Bakanlığı 2013-2017 Stratejik Eylem Planı, https://www.saglik.gov.tr/ SaglikTurizmi/dosya/1-82339/h/2013-2017stratejikplan.pdf (20.05.2016).

Sağıık Bakanlığı Sağıık Turizmi Web Sitesi, http://saglikturizmi.gov.tr/ (01.02.2016).

Schmalleger, D., ve Carson, D. (2008), 'Blogs in tourism: Changing Approaches to Information Exchange', Journal of Vacation Marketing, 14(2), ss. 99-110.

Sharifpour, M., Walters, G., Ritchie, B. W. ve Winter, C. (2014), 'InvestigatiOng the Role of Prior Knowledge in Tourist Decision Making: A Structural Equation Model of Risk Perceptions and Information Search', Journal of Travel Research, 53(3), ss. 307-322.

Srivastava, R. (2006), 'Indian Society for Apheresis and Apheresis Tourism in India Is there a future?', Transfusion and Apheresis Science, 34, ss. 139-144.

Tapachai, N. ve Waryszak, R. (2000), 'An Examination of the Role of Beneficial Image in Tourist Destination Selection', Journal of Travel Research, 39, ss. 37-44.

Türkiye Medikal Turizm Değerlendirme Raporu (2013), Türkiye Cumhuriyeti Sağlık Bakanlığı Sağlık Hizmetleri Genel Müdürlüğü Sağlık Turizmi Daire Başkanlığı, Hazırlayanlar: Prof. Dr. Sıdıka Kaya, Doç. Dr. Hasan Hüseyin Yıldırım, Arş. Gör. Uzm. Seda Karsavuran, Arş. Gör. Özlem Özer, Katkıda Bulunanlar: Prof. Dr. İran Şencan, Dr. Dursun Aydın, http://www.saglikturizmi.org.tr/yonetim/templates/ addons/ckfinder/userfiles/TMTD_2013_raporu.pdf (15.05.2016)

Westbrook, R. A. (2014), 'Product/Consumption-Based Affective Responses and Postpurchase Processes', Journal of Marketing Research, 24(3), ss. 258-270.

Woodman, J. (2009), Patients Beyond Borders Turkey Edition: Everybody's Guide to Affordable, World-Class Medical Tourism, Healthy Travel Media.

World Health Organization (WHO), Basic Documents, Forty-fifth edition, Supplement, http://www.who.int/governance/eb/who_constitution_en.pdf (01.02.2016).

Xiang, Z. ve Gretze, U. (2010), 'Role of Social Media in Online Travel Information Search', Tourism Management, 31, ss. 179-188.

Yurdakul, N. B. ve Coşkun, G. (2008), 'Fakültelerde Web Sitelerinin Kurumsal Tanıtım Amaçı Kullanımı: İletişim Fakülteleri Web Siteleri Üzerine Bir Araştırma', İstanbul Üniversitesi İletişim Fakültesi Dergisi, 33, ss. 141-156. 